\title{
Composition, Occurrences and Checklist of Periphyton Algae of Some Water Bodies Around Benin City, Edo State, Nigeria *Osagie Ekhator
}

\begin{abstract}
This paper presents an investigation of the periphyton algae of five rivers around Benin City. The rivers studied were River Okhuaihe (station 1), River Ikpoba (station II), River Ossiomo, Ologbo station (station III), River Siluko (station IV) and River Ogba (station V). Samples were collected monthly for periphyton and physico-chemical analysis. Periphyton samples were collected by scraping the roots, leaves and stems of aquatic macrophytes, dead and felled logs submerged on the banks of the rivers as well as from rocks embedded in the substratum while water samples for physical and chemical parameters were collected directly into clear plastic containers. The rivers were acidic with a $\mathrm{pH}$ range of 5.10-6.31 and very low in nutrients. A total of 87 taxa of periphyton algae were identified and categorized into 4 divisions, 11 orders, 9 families and 44 genera. The distribution among the division was Chlorophyta 64.37\%, Bacillariophyta $22.99 \%$, Cyanophyta $5.75 \%$ and Euglenophyta $6.89 \%$. The majority of the green periphyton algae were desmids.
\end{abstract}

Key words: $\quad$ Periphyton, rivers, physico-chemical, taxa.

\section{Introduction}

ll water bodies in the tropics have
submerged substrates (stones, plants and logs) covered at least in part by a community of periphyton. The factors controlling the species composition, distribution and biomass of periphyton species are physicochemical, biological and hydrological cycle (Chindah, 2004). Periphyton is a complex mixture of algae, cyanobacteria, heterotrophic microbes and detritus that attached to submerged surfaces in most aquatic ecosystem. It serves as an important food source for invertebrates, tadpoles and some fish. It is exposed to contaminants in the water column and can absorb them into their body tissues. The periphyton is also an important indicator of water quality (Azim et al, 2006).

Attached algae are primitive plants that get their nutrients from water passing over them. Almost every part of an algal cell takes up nutrients. Terrestrial plants take nourishment primarily from only specialized cells in their roots. Algae utilize utilize carbondioxide during photosynthesis to produce food which the other rung in the aquatic food chain depend directly or indirectly on as food source. Periphyton is capable of nutrient pollution removal down to very low pristine ranges. Reports on algal periphyton community includes those of Chindah (2004), Chindah et, al (2006).

There is a dearth of information on periphyton algae in these rivers. This paper aims to investigate the composition and occurrence of the periphyton algae in the different rivers as well as provide a background information on the physical, chemical and trophic status of the rivers.

\section{Study Area \\ In this study, rivers (Okhuaihe, Ikpoba,} Ossiomo, Siluko and Ogba) were investigated. The rivers are situated at extreme ends of Benin City and are affected by two main climates; the dry season which commences in November till April. It is often accompanied by dry, dusty harmattan winds from December to January, and the rainy season starts in May and continues till October or November. The river waters are fresh in both seasons as there is no influence of sea water. Human activities on the rivers include fishing, washing or clothes and commercial activities.

\section{Methodology}

Samples for the study were collected on monthly basis for eight months from December 2001 to July 2002, for both physical and chemical factors and periphyton algae. Standard methods as described in APHA (1985) were followed for the determination of water quality parameters studied at the Benin Owena River Basin Laboratory in the University of Benin. At each station, water temperature was measured using mercury in glass thermometer. $\mathrm{pH}$ values of the water samples were determined by using a Jenway digital $\mathrm{pH}$ meter model 3305. Means of mostly readings were calculated for all variables. Analysis of variance (ANOVA) was also performed to detect significant difference between stations. Periphyton samples were scraped from roots, leaves and stems of aquatic macrophytes, dead and felled logs submerged on the banks of the rivers as well as from rocks embedded in the substratum. The periphyton samples were preserved in a solution of $4 \%$ formaldelyde in a $500 \mathrm{ml}$ plastic container. 
Examination was done at the phycology laboratory in the University of Benin in Benin City using Leitz Orthoplan Universal WideField micro scope equipped with tracing and measuring devices while identification and classification of periphyton algae were carried out with the aid of the works and publications of Kadiri (1987) and Opute (1991, 2000 and 2003).

\section{Results}

\section{Physico-Chemical Parameters}

The minimum $\mathrm{pH}$ of 5.10 in April was recorded in station 1 while the highest of 6.67 was recorded in station 2 in January. The recorded temperature ranged between $27.87^{\circ} \mathrm{C}$ and $30.50^{\circ} \mathrm{C}$ for air and $25.56^{\circ} \mathrm{C}-27.18^{\circ} \mathrm{C}$ for water. Total dissolved solids ranged between $22.13 \mathrm{mg} / \mathrm{l}$ in station 4 to $32.12 \mathrm{mg} / \mathrm{l}$ in station 1. Dissolved oxygen values ranged between $6.25 \mathrm{mg} / 10.03$ in station 2 to $7.00 \mathrm{mg} / \mathrm{l}$. Lowest sulphate value was 0.03 in station 1 and highest was $0.11 \mathrm{mg} / \mathrm{l}$ in station 4 . The minimum value of nitrate was recorded in stations 1 and 5 $(0.04 \mathrm{mg} / \mathrm{l}$ respectively) and the highest, $0.09 \mathrm{mg} / \mathrm{l}$ in station 4. Highest phosphate concentration was $0.36 \mathrm{mg} / \mathrm{l}$ in station 4 and lowest concentration was $0.30 \mathrm{mg} / \mathrm{l}$ in stations 2 , 3 and 5 (see Table 1).

\section{Periphyton Composition}

A total of 87 taxa of periphyton belonging to four divisions-Chlorophyta (56), Bacillariophyta (20), Cyanophyta (5) and Euglenophyta (6) were identified (see Table 2).

The Chlorophyta were represented by 6 orders and 9 families. The orders were Zygnematales, Chlorococcales, Oedogoniales, Ulotricales, Siphonocladales and Volvocales. The families on the other hand were Desmidiaceae,Gonatozygonaceae,

Mesotaeniaceae,Zygnemataceae,

cenedesmaceae.Oedogoniaceae, Ulotrichaceae, Cladophoraceae, Volvocaceae. The order Zygnematales constituted the bulk of Chlorophyta with a record of over half of the taxa found. They were mainly members of Desmidiaceae.

The Bacillariophyta were represented by 2 orders, the Centrales (families Coscinodiscaceae, Melosiraceae and Thalassiosiraceae) and Pennales (families Naviculaceae, Eunotiaceae, Diatomaceae and Surirellaceae). Of all these families, Naviculaceae (6 taxa) and Diatomaceae (7 taxa) were better represented than others. Cyanophyta was represented by Chroococcales (family
Chroococaceae) and Nostocales (family Oscillatoriaceae) with 2 and 3 taxa each. Euglenophyta were entirely Euglenales (family Euglenaceae) being represented by species of Euglena (2), Leopocinclis (1), Phacus (1) and Trachelomonas (2).

Generally, the division Chlorophyta constitute about $64.37 \%$ of the entire periphyton algal population. About $41.3 \%$ of this was made of desmids. Bacillariophyta accounted for $22.99 \%$ of the total periphyton algae of which the pennate forms dominated by $19.4 \%$. A contribution of $5.75 \%$ and $6.89 \%$ was made by members of the Cyanophyta and Euglenophyta divisions respectively as shown in Figure 1.

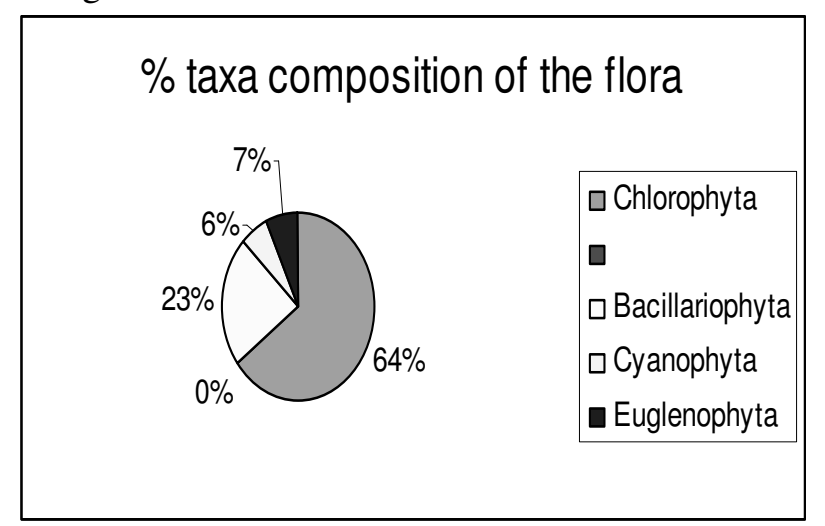

Fig 1: Percentage composition of periphyton algae in studied water bodies area

\section{Distribution}

Majority of the diatoms (Bacillariophyta) were found in stations 1, 3 and 4 . The Chlorophyta members were mostly seen in stations 1 and 3 while some Cyanophyta and Euglenophyta members where mostly found in station 4 (see Table 3).

Specifically, taxa which occurred in 3 stations and above include, Frustulia rhomboides, Naviculla sp, Eunotia flexuosa and Fragillaria sp. (for diatoms) and Closterium libellula, $\mathrm{Cl}$. pseudolunula, Cosmarium contractum, C. sp., Hyalotheca dissiliens, Spirogyra dudia and $S$. sp. (for Chlorophyta). Other species occurred in 1 or 2 stations only.

\section{Discussion}

The acidic $\mathrm{pH}$ observed in the rivers is expected and has been reported in similar river systems where liter falls underlying the river bed impacts on the water through the process of decay thereby introducing humic substances that induce acidic conditions (Chindah et al, 2006). The acidic nature of the $\mathrm{pH}$ values is also attributable to geological and biochemical 
factors within the river catchment, which may be poor in lime or silica (Akpan et al, 2003).

Relatively higher values of air and water temperatures were recorded in the dry months (December to March) than in the wet months (April to July). This could be attributed to increased cloud cover and consequent reduction in solar radiation (Onyema, 2007).

Values for total dissolved solids were low throughout the study, an indication that the rivers were not under intense pressure from pollution such as untreated sewage, sawdust, petrochemical materials, detergent and industrial effluents (Onyema, 2007).

Mean dissolved oxygen concentration ranged from $6.25 \pm 0.56 \mathrm{mg} / \mathrm{l}$ to $7.35 \pm 0.52 \mathrm{mg} / \mathrm{l}$ and shows that the running waters were well aerated irrespective of stations. This is expected as it is a running water where dissolved oxygen is usually a limiting factor due to direct diffusion at the surface and surface water agitation like turbulence (Imoobe and Oboh, 2003 and Kadiri, 2000).

Nutrients (sulphate, nitrate and phosphate) values were low throughout the study, an indication of their low concentration in the surrounding watershed. The water bodies in stations 1,2 and 5 were poor in nutrient which may have resulted in the non-occurrence of these divisions. Saliu and Ekpo (2006), supported this by stating that increase in nutrient elements, $\mathrm{PO}_{4^{-}}$and $\mathrm{NO}_{3}^{-}$suggested organic pollution and nutrient enrichment.

In eutrophic and hypereutrophic waters where high nutrients are being supplied continuously, the high level of nutrient would also support the coexistence of many phytoplankton species and high productivity, resulting in high diversity (Ichimura and Ogawa, 1984). But from this study, low level of nutrients was observed. On the other hand, the scouring effect of floodwaters could have dislodged attached forms, leading to a reduction of occurrence of members of these divisions (Onyema, 2007). A total of 87 taxa of periphyton algal flora were identified. The periphyton algal community observed in this study is taxonomically dominated by Chlorophyta $64.37 \%$ followed by Bacillariophyta 22.99\%, Euglenophyta and Cyanophyta with $6.89 \%$ and $5.75 \%$ respectively. The order of dominance of the major algal groups in this study is however at variance with the report of Chindah et al
(2006), who stated that the general trend of the community structure pattern of Bacillariophyceae, > Chlorophyceae, > Euglenophyceae, $>$ Chlorophyceae had been the trend reported for most freshwater systems with limited disturbance. However, the difference in algal assemblages between stations in this study and the above trend, may be explained in part by the microhabitat differences in water quality habitat variability and perturbation which corresponds to the occurrence of some species particularly members of the Chlorophyta group (Chindah,2004).

There were variations in the periphyton species assemblages amongst the stations studied. In station 1, the division Chlorophyta occurred most with a wide assortment of desmids occurring freely (41.3\%). Particularly impressive among the desmids were the genera Cosmarium and Closterium. Members of the Volvocales (Eudorina, Pandorina, Pleodorina and Volvox) and Zygnematales (different species of Spirogyra and Mougeotia) also occurred. The high percentage of desmids in this study could be that they are typically freshwater and characteristic of acidic and nutrient poor aquatic ecosystems (Kadiri,2002). The occurrence of abundance of desmids is an indication that the water body is largely unpolluted (Kadiri and Omozusi, 2002). The diatoms species found in the different stations included the genera, Melosira, Synedra, Eunotia and Frustulia. Diatoms encountered in this study occurred in all the stations with slight variations but more occurring in station 1 and the lowest species occurring in station 5 . The pennate forms dominated with $19.4 \%$. The dominant pennate genera were Frustulia and Fragillaria. 43 diatoms species belonging to 19 genera and dominated by pennate forms were recorded in the investigations of bottom dwelling diatoms of a West African Lagoon sewage disposal site (Nwankwo, 1994). Members of the Cyanophyta and Euglenophyta divisions did not occur in stations 1,2 and 5 . This could be attributed to the lack of activities such as auto mechanic workshops and other domestic discharges in the stations which would have enhanced the occurrence of the blue-green algae (Chindah et al, 2006). This was also corroborated by the report of Kadiri (1999), who reported that euglenoids and bluegreens could be qualitatively less numerous as they are characteristic of eutrophic or nutrient 
rich water bodies.Substrate preference may have been responsible for the higher occurrence of some divisions over others as observed in this study. It is necessary to suggest that the

\section{References}

APHA, (1985), American Public Health

Association. Standard methods for the

examination of water and wastewater. $16^{\text {th }}$

edition. APHA, AWWA. WPCF.Washington

D. C.

Azim, M.E., Verdegem, M.C.J., VanDam,A.A and Beveridge, M.C.M. (2006), Periphyton. Ecology, Exploitation and Management. Oxford University Press, 352pp.

Chindah, A.C. (2004), Response of periphyton community to salinity gradient in tropical estuary,Niger Delta. Polish journal of Ecology, 52(1), 83-89.

Chindah, A.C., Braide, S.A. Obianefo, F. and Obunwo, C.C. (2006), Water quality and periphyton community of a stream system receiving municipal waste discharges in Rivers State, Niger Delta, Nigeria. Estud. Bio, 28(4), 73-89.

Ekpo, M.P. and Saliu, J.K. (2006), Preliminary chemical and biological assessment of Ogbe creek, Lagos, Nigeria. West Africa Journal of Applied Ecology, 9,14-22.

Gaiser, E.E., Childers, D.L., Jones, R.D., Richards, J.H., Scinto, L.J., Trexler, J.C. (2006), Periphyton responses to eutrophication in the Florida Everglades: Cross-system patterns of structural and compositional change. Limnol Oceanogr., 51(1 part 2), 617630.

Ichimura, S. and Ogawa, Y. (1984), Phytoplankton diversity in inland waters of different trophic status. Jap. J. Limnol., 45(3), 173-177.

Imoobe, T. O. T. and Oboh, I. P. (2003), Physical and chemical hydrology of River Jamieson, Niger Delta, Nigeria. Benin Sci. Dig. 1:105-119.

Kadiri, M.O. (1987), Algae and primary Productivity studies of Ikpoba reservoir.

\section{Acknowledgement}

I acknowledge the support and encouragement of Prof. F. I. Opute, Prof. (Mrs.) M. O. Kadiri, Dr. C .O. Akoma, and Mr. Tunde Tenabe, who assisted me in the identification of a number of taxa. I also thank Dr. (Mrs.) F. Ogbe and Mr. E. Akpaja for their assistance and the Department of Botany, University of Benin, Benin City for providing the materials used in this work. substrate type and some environmental attributes are critical to the development of periphyton (Chindah,2004).

Unpublished Ph.D. Thesis, University of Benin, Benin City.

Kadiri, M.O. (1999), A spatial profile of net Phytoplankton in the lower River Niger Recorded in the wet season. Acta Hydrobiol, 41(3/4), 247-258.

Kadiri, M. O. (2000), Seasonal trend in the chemical limnology of a shallow Nigerian man-made lake. Acta Hydrobiol. 42(1/2), 2940.

Kadiri, M.O. (2002), A checklist of desmids in Nigeria. Global Journal of Pure and Applied sciences. 8(2), 223-237.

Kadiri, M.O. and Omozusi, H.I. (2002), A pre-pollution study of the phytoplankton of an oligotrophic river in southern Nigeria. Afr.I.Environ.Pollut.Health 1(1), 19-27.

Nwankwo, D.I. (1994), Hydrochemical properties and bottom dwelling diatoms of a Lagos lagoon sewage disposal site. Polskie Archiwun Hydrobiologii. 41, 35-47.

Onyema, I.C. (2007), The phytoplankton composition, abundance and temporal variation of a polluted estuarine creek in Lagos, Nigeria. Turkish Journal of Fisheries and Aquatic sciences, 7, 89-96.

Opute, F.I. (1991), A checklist of the freshwater, brackish and marine phytoplankton of the Warri/Forcados estuaries of Southern Nigeria. Nigeria_Journal of Botany, 4, 227254.

Opute, F.I. (2000), Contribution to the knowledge of algae of Nigeria. I.Desmids from the Warri/Forcados estuaries.Part 11. The Elongate baculiform desmids J. limnol., 59(2), 131-155.

Opute, F.I. (2003), Contribution to the knowledge of algae of Nigeria Chlorophyceae from the Warri/Forcados estuaries.Part 1. The orders Volvocales and Chloroccocales. Benin sci. Dig.1, 31-52. 
Table 1:Physico-Chemical parameters

\begin{tabular}{|c|c|c|c|c|c|c|c|c|c|c|}
\hline Parameters & $\begin{array}{r}\mathrm{S} \\
\text { Okl }\end{array}$ & laihe & & $\begin{array}{l}.2 \\
\text { ba }\end{array}$ & Ossiol & $\begin{array}{l}\text { Г.3 } \\
\text { p-Ologbo }\end{array}$ & & .4 & & \\
\hline $\mathbf{P}^{\mathrm{H}}$ & $\begin{array}{l}5.10- \\
6.12\end{array}$ & $\begin{array}{l}5.56 \\
\pm 0.11\end{array}$ & $\begin{array}{l}5.44- \\
6.67\end{array}$ & $\begin{array}{l}5.93 \\
\pm 0.17\end{array}$ & $\begin{array}{l}5.21- \\
6.40\end{array}$ & $\begin{array}{l}5.79 \\
\pm 0.12\end{array}$ & $\begin{array}{l}5.57- \\
7.20\end{array}$ & $\begin{array}{l}6.31 \\
\pm 0.17\end{array}$ & $\begin{array}{l}5.33- \\
6.25\end{array}$ & $\begin{array}{l}5.76 \\
\pm 0.12\end{array}$ \\
\hline $\begin{array}{l}\text { Air Temperature } \\
{ }^{0} \mathrm{C}\end{array}$ & $\begin{array}{l}27.50- \\
30.20\end{array}$ & $\begin{array}{r}28.27 \\
\pm 0.37\end{array}$ & $\begin{array}{l}27.50- \\
36.80\end{array}$ & $\begin{array}{l}30.03 \\
\pm 1.2\end{array}$ & $\begin{array}{l}29.00- \\
35.00\end{array}$ & $\begin{array}{l}\mathbf{3 0 . 5 0} \\
\mathbf{+ 0 . 7 5}\end{array}$ & $\begin{array}{l}27.00- \\
32.50\end{array}$ & $\begin{array}{l}28.87 \\
\pm 0.60\end{array}$ & $\begin{array}{l}27.00- \\
32.50\end{array}$ & $\begin{array}{l}28.87 \\
\pm 0.60\end{array}$ \\
\hline $\begin{array}{l}\text { Water } \\
\text { Temperature }{ }^{0} \mathrm{C}\end{array}$ & $\begin{array}{l}24.00- \\
26.50\end{array}$ & $\begin{array}{l}25.50 \\
\pm 0.33\end{array}$ & $\begin{array}{l}24.50- \\
27.00\end{array}$ & $\begin{array}{r}25.87 \\
\pm 0.27\end{array}$ & $\begin{array}{l}25.00 \pm \\
28.00\end{array}$ & $\begin{array}{l}26.87 \\
\pm 0.36\end{array}$ & $\begin{array}{l}26.00- \\
29.50\end{array}$ & $\begin{array}{l}27.18 \pm \\
0.45\end{array}$ & $\begin{array}{l}25.00- \\
27.00\end{array}$ & $\begin{array}{l}26.25 \\
\pm 0.23\end{array}$ \\
\hline $\begin{array}{lr}\text { Total } & \text { dissolved } \\
\text { solids }(\mathrm{TDS})(\mathrm{Mg} / \mathrm{l})\end{array}$ & $\begin{array}{l}25.10- \\
35.50\end{array}$ & $\begin{array}{l}32.12 \pm \\
1.50\end{array}$ & $\begin{array}{l}19.40- \\
41.00\end{array}$ & $\begin{array}{l}28.66 \\
\pm 2.94\end{array}$ & $\begin{array}{l}18.40 \pm \\
45.00\end{array}$ & $\begin{array}{l}29.22 \\
\pm 3.09\end{array}$ & $\begin{array}{l}15.50- \\
34.00\end{array}$ & $\begin{array}{l}22.13 \pm \\
5.59\end{array}$ & $\begin{array}{l}21.50- \\
42.50\end{array}$ & $\begin{array}{l}31.21 \\
\pm 2.69\end{array}$ \\
\hline $\begin{array}{ll}\text { Nitrate } & \left(\mathrm{NO}_{3}\right) \\
(\mathrm{Mg} / \mathrm{l}) & \end{array}$ & $\begin{array}{l}\text { 0.03- } \\
0.07\end{array}$ & $\begin{array}{l}0.04 \pm 0 . \\
004\end{array}$ & $\begin{array}{l}0.05- \\
0.10\end{array}$ & $\begin{array}{l}\mathbf{0 . 0 7} \\
\mathbf{\pm 0 . 0 0 7}\end{array}$ & $\begin{array}{l}0.04- \\
0.01\end{array}$ & $\begin{array}{l}0.07 \\
\pm 0.008\end{array}$ & $\begin{array}{l}0.05- \\
0.14\end{array}$ & $\begin{array}{l}0.09 \pm 0 . \\
009\end{array}$ & $\begin{array}{l}0.02- \\
0.07\end{array}$ & $\begin{array}{l}0.04 \\
\pm 0.005\end{array}$ \\
\hline $\begin{array}{l}\text { Sulphate } \quad \text { SO }_{4} \\
(\mathrm{Mg} / \mathrm{l})\end{array}$ & $\begin{array}{l}0.02- \\
0.05\end{array}$ & $\begin{array}{l}0.03 \pm 0 . \\
004\end{array}$ & $\begin{array}{l}0.08- \\
0.14\end{array}$ & $\begin{array}{l}\mathbf{0 . 1 0} \\
\mathbf{\pm 0 . 0 0 7}\end{array}$ & $\begin{array}{l}0.05- \\
0.12\end{array}$ & $\begin{array}{l}0.08 \\
\pm 0.008\end{array}$ & $\begin{array}{l}0.07- \\
0.16\end{array}$ & $\begin{array}{l}0.11 \pm 0 . \\
01\end{array}$ & $\begin{array}{l}0.03- \\
0.17\end{array}$ & $\begin{array}{l}0.09 \\
\pm 0.01\end{array}$ \\
\hline $\begin{array}{l}\text { Phosphate } \\
\left(\mathrm{PO}_{4}\right)(\mathrm{Mg} / \mathrm{l})\end{array}$ & $\begin{array}{l}0.21- \\
0.46\end{array}$ & $\begin{array}{l}0.31 \pm 0 . \\
03\end{array}$ & $\begin{array}{l}0.19- \\
0.44\end{array}$ & $\begin{array}{l}0.30 \\
\pm 0.02\end{array}$ & $\begin{array}{l}0.13- \\
0.42\end{array}$ & $\begin{array}{l}0.30 \\
\pm 0.03\end{array}$ & $\begin{array}{l}0.14- \\
0.52\end{array}$ & $\begin{array}{l}0.36 \pm 0 . \\
04\end{array}$ & $\begin{array}{l}0.17- \\
0.41\end{array}$ & $\begin{array}{l}0.03 \\
\pm 0.03\end{array}$ \\
\hline
\end{tabular}

Table 2: $\quad$ Periphyton algal composition of some water bodies around Benin City

\begin{tabular}{|l|l|l|l|l|l|l|}
\hline Division & Classes & Orders & Families & Genera & Total taxa & $\begin{array}{l}\text { \% taxa } \\
\text { composition } \\
\text { of the flora }\end{array}$ \\
\hline Chlorophyta & Chlorophyceae & 6 & 9 & 26 & 56 & 64.37 \\
\hline Bacillariophyta & Bacillariophyceae & 2 & 7 & 11 & 20 & 22.99 \\
\hline Cyanophyta & Cyanophyceae & 2 & 2 & 3 & 5 & 5.75 \\
\hline Euglenophyta & Euglenophyceae & 1 & 1 & 4 & 6 & 6.89 \\
\hline Total 4 & $\mathbf{4}$ & $\mathbf{1 1}$ & $\mathbf{1 9}$ & $\mathbf{4 4}$ & $\mathbf{8 7}$ & $\mathbf{1 0 0 . 0 0}$ \\
\hline
\end{tabular}


Table 3: Periphyton checklist and occurrence in The Studied water bodies around Benin City.

\begin{tabular}{|c|c|c|c|c|c|}
\hline DIVISION: BACILLARIOPHYTA & $\begin{array}{l}\text { ST. } \\
\text { Okhuaihe }\end{array}$ & $\begin{array}{l}\text { ST2 } \\
\text { Ikpoba }\end{array}$ & $\begin{array}{l}\text { ST3 } \\
\text { Ossiomo } \\
\text {-Ologbo) }\end{array}$ & $\begin{array}{l}\text { ST4 } \\
\text { Siluko }\end{array}$ & $\begin{array}{l}\text { ST5 } \\
\text { Ogba }\end{array}$ \\
\hline $\begin{array}{l}\text { CLASS: Bacillariophyceae } \\
\text { ORDER: Centrales } \\
\text { Family: Conscinodiscaceae } \\
\text { Genus: Conscinodiscus Ehrenberg } \\
\text { Conscinodiscus centralis Ehrenberg }\end{array}$ & + & & & & \\
\hline $\begin{array}{l}\text { Family: Melosiraceae } \\
\text { Genus: Melosira Agardh } \\
\text { Melosira nyassensis Muller var. victoriae } \\
\text { Muller }\end{array}$ & + & & + & & \\
\hline $\begin{array}{l}\text { Family: Thalassiosiraceae } \\
\text { Genus: Aulacoseira Thwaites } \\
\text { Aulacoseira granulata var. angustissima } \\
\text { (Muller) Simonsen }\end{array}$ & + & & + & & \\
\hline ORDER: Pennales & & & & & \\
\hline $\begin{array}{l}\text { Family: Naviculaceae } \\
\text { Genus: Cymbella Agardh } \\
\text { Cymbella sp. } \\
\text { Genus: Frustulia Rabenh } \\
\text { Frustulia rhomboides (Ehr.) DeToni }\end{array}$ & + & + & $\begin{array}{l}+ \\
+\end{array}$ & + & \\
\hline
\end{tabular}


Table 3 contd.

\begin{tabular}{|c|c|c|c|c|c|}
\hline \multirow{4}{*}{$\begin{array}{l}\text { Genus: Navicula Rabenh } \\
\text { Navicula } \mathrm{sp} . \\
\text { Genus: Pinnularia Ehrenberg } \\
\text { Pinnularia cardinaliculus Cleve }\end{array}$} & ST 1 & ST. 2 & ST. 3 & ST. 4 & ST. 5 \\
\hline & & & & & \\
\hline & + & + & + & & \\
\hline & & & & & + \\
\hline $\begin{array}{l}\text { P. subcapita Greg. } \\
\text { P. viridis (Nitzsch) Ehr. } \\
\text { Family: Eunottiaceae } \\
\text { Genus: Eunotia } \text { Ehrenberg } \\
\text { Eunotia flexuosa } \text { Breb and Kutz }\end{array}$ & + & & + & + & \\
\hline $\begin{array}{l}\text { E. monodon (Ehr). var. tropica Hust. } \\
\text { E. garussica Choln. }\end{array}$ & & & & + & + \\
\hline $\begin{array}{l}\text { Family: Diatomaceae } \\
\text { Genus: Fragillaria Lyngb. } \\
\text { Fragillaria javanica } \text { Hustedt }\end{array}$ & + & & + & & \\
\hline $\begin{array}{l}\text { F. sp. } \\
\text { Genus: Synedra } \text { Ehrenberg } \\
\text { Synedra acus Kutz. }\end{array}$ & + & + & + & $\begin{array}{l}+ \\
+ \\
\end{array}$ & \\
\hline $\begin{array}{l}\text { S. superba Kutz } \\
\text { S. ulna (Nitzsch) Her } \\
\text { Genus: Tabellaria } \text { Ehrenberg } \\
\text { Tabellaria } \text { sp }\end{array}$ & $\begin{array}{l}+ \\
+\end{array}$ & & + & + & \\
\hline T. flocculosa (Rothe) Kutz. & & & & & + \\
\hline $\begin{array}{l}\text { Family: Surirellaceae } \\
\text { Genus: Surirella Turp. } \\
\text { Surirella elegans } \text { Ehr. }\end{array}$ & & & + & + & \\
\hline $\begin{array}{l}\text { C. sabbulteum Schmidle var. maius Thom } \\
\text { C. subariculatum West var. bogoriense } \\
\text { (Bern) }\end{array}$ & $\begin{array}{l}+ \\
+\end{array}$ & & & & \\
\hline $\begin{array}{l}\text { C. sp. } \\
\text { Genus: Desmidium (Agardh) Ralfs } \\
\text { Desmidium quadratum Nordst } \\
\text { Genus: Euastrum (Ehrenberg) Ralfs. } \\
\text { Euastrum ansatum Ehr. }\end{array}$ & + & & + & $\begin{array}{l}+ \\
+ \\
\end{array}$ & + \\
\hline $\begin{array}{l}\text { horikawae Ehr. } \\
\text { Genus: Hyalotheca (Ehrenberg) Ralfs. } \\
\text { Hyalotheca dissiliens (Smith) Breb. } \\
\text { Genus: Micrasteria (Agardh) Ralfs } \\
\text { Micrasterias jenneri var. simplex West } \\
\text { and West } \\
\text { Genus: Pleurotaenium Nageli } \\
\text { Pleurotaenium ovatum Nordst. }\end{array}$ & $\begin{array}{l}+ \\
+ \\
+\end{array}$ & & + & & + \\
\hline $\begin{array}{l}\text { Pl. coronatum (Turn.) W. and G.S West } \\
\text { var africanum Schmid }\end{array}$ & + & & & & + \\
\hline $\begin{array}{l}\text { Pl. coronatum (Breb) Rabenh } \\
\text { Genus: Sphaerozosma Corda } \\
\text { Sphaerozosma granulatum Roy and Biss. }\end{array}$ & & & & & $\begin{array}{l}+ \\
+ \\
\end{array}$ \\
\hline
\end{tabular}


Table 3 contd.

\begin{tabular}{|c|c|c|c|c|c|}
\hline $\begin{array}{l}\text { DIVISION: CHLOROPHYTA } \\
\text { CLASS: Chlorophyceae } \\
\text { ORDER: Zygnematales }\end{array}$ & ST 1 & ST.2 & \begin{tabular}{|l|} 
ST. 3 \\
\end{tabular} & \begin{tabular}{|l|} 
ST. 4 \\
\end{tabular} & ST. 5 \\
\hline $\begin{array}{l}\text { FAMILY: Desmidiaceae } \\
\text { Genus: Actinotaenium Teiling } \\
\text { Actinotaenium globossum (Buln) Forster }\end{array}$ & & & & & + \\
\hline $\begin{array}{l}\text { mooreanum (Arch) Teil. var. mooreanum } \\
\text { Genus: Bambusina (Kutz.) Ralfs } \\
\text { Bambusina brebissoni Kutz. var. maius (Racib) Croasd. } \\
\text { Genus: Closterium (Nitzsch) Ralf } \\
\text { Closterium acerosum (Schr.) Ehr. var. elongatum Breb. }\end{array}$ & $\begin{array}{l}+ \\
+\end{array}$ & & + & + & \\
\hline Cl. dianae Ehr. & + & & & & \\
\hline Cl. calasporum Wittr. & + & & & & \\
\hline Cl. leiblenii Kutz. & & + & & & \\
\hline Cl. libebulla Focke var. interruptum (West and West) Donat & + & & & + & + \\
\hline Cl. lunula (Mull) Nitzsch ex Ralfs & + & & & & \\
\hline Cl. pseudolunula Borge var. concavum Forest and Eckert & + & + & + & & \\
\hline Cl. setaceaum (Ehr) Ralfs & & & + & & \\
\hline Cl. turgidum (Her) var. borgei (Borge) Defl. & + & & & + & \\
\hline Genus: Cosmarium Corda & & & & & \\
\hline Cosmarium askenasyi Schmidle $f$. latum Scot and Presc. & + & & & + & \\
\hline C. contractum Kich f. jacobsenin (Roy) West and West & + & + & & & + \\
\hline C. decoratum West and West & & & + & & \\
\hline C. hammeri Reinsch var. africanum Fritsch and Rich & & & + & & \\
\hline C. pectinatum Breb. var. inevolutum West and West & & & & + & \\
\hline C. Pseudoconnatum Nordst & + & & & & \\
\hline C. quadrum Lund & + & & & & \\
\hline C. spinuliferum West and West & & & & & + \\
\hline $\begin{array}{l}\text { S. sp. } \\
\text { Genus: Staurastrum Meyen } \\
\text { Staurodesmus glabus (Ehr) Teil f. } \\
\text { Subglabrus (Groubl. Teil) }\end{array}$ & + & & & + & \\
\hline $\begin{array}{l}\text { Family: Gonatozygonaceae } \\
\text { Genus: Gonatozygon DeBary } \\
\text { Gonatozygon aculeatum Hastings }\end{array}$ & & & & & + \\
\hline $\begin{array}{l}\text { Family: Mesotaeniaceae } \\
\text { Genus: Cylindrocystis (Menegh) Ralfs } \\
\text { Cylindrocystis brebessoni Menegh } \\
\text { Genus: Netrium (Nageli) Itzigs and Rothe } \\
\text { Netrium digitus (Ehr) Itzigs and Rothe var. lamellosum } \\
\text { (Breb) Gronbl. }\end{array}$ & & & & + & + \\
\hline $\begin{array}{l}\text { Family: Zygnemataceae } \\
\text { Genus: Mougeotia Agardh } \\
\text { Mougeotia sphaerocarpa Wolle }\end{array}$ & + & & + & & \\
\hline M. sp & + & & + & & \\
\hline $\begin{array}{l}\text { Genus: Spirogyra Link } \\
\text { Spirogyra communis (Hass.) Kutz }\end{array}$ & + & & + & & \\
\hline $\begin{array}{l}\text { S. dubia Kutz } \\
\text { S. variance (Hass) Kutz. }\end{array}$ & + & $\begin{array}{l}+ \\
+\end{array}$ & + & & \\
\hline
\end{tabular}


Table 3 contd.

\begin{tabular}{|c|c|c|c|c|c|}
\hline & ST. 1 & ST2 & ST3 & ST4 & ST5 \\
\hline $\begin{array}{l}\text { S. sp } \\
\text { ORDER: Chlorococcales } \\
\text { Family: Scenedesmaceae } \\
\text { Genus: Scenedesmus Meyen } \\
\text { Scenedesmus ecornis (Ehr.) Chod. var. polymorphus } \\
\text { Chod. }\end{array}$ & & + & + & + & + \\
\hline $\begin{array}{l}\text { ORDER: Oedogoniales } \\
\text { Family: Oedogoniaceae } \\
\text { Genus: Bulbochaete Agardh } \\
\text { Bulbochaete nigeria Gantheir-Lieure } \\
\text { Genus: Oedogonium Link } \\
\text { Oedogonium grande Kutz. }\end{array}$ & & & $\begin{array}{l}+ \\
+\end{array}$ & & \\
\hline $\begin{array}{l}\text { O. suecicum Wittr } \\
\text { ORDER: Ulotricales }\end{array}$ & + & & + & & \\
\hline $\begin{array}{l}\text { Family: Ulotrichaceae } \\
\text { Genus: Ulothrix Kutz. } \\
\text { Ulothrix tenuissima Kutz. }\end{array}$ & & & + & & \\
\hline $\begin{array}{l}\text { ORDER: Volvocales } \\
\text { Family: Volvocaceae } \\
\text { Genus: Eudorina Ehrenberg }\end{array}$ & & & & & \\
\hline $\begin{array}{l}\text { Eudorina elegans Ehr. } \\
\text { Genus: Pandorina Bory } \\
\text { Pandorina morum (Mull) Bory }\end{array}$ & & & & + & + \\
\hline$P . \mathrm{sp}$ & & & & + & \\
\hline $\begin{array}{l}\text { Genus: Pleodorina Shaw } \\
\text { Pleodorina illinoisensis (Kofoid) } \\
\text { Genus: Volvox Linnaeus }\end{array}$ & & & & + & \\
\hline Volvox Africana & & & + & & \\
\hline $\begin{array}{l}\text { DIVISION: CYANOPHYTA } \\
\text { CLASS: Cyanophyceae } \\
\text { ORDER: Chroococcales }\end{array}$ & & & & & \\
\hline $\begin{array}{l}\text { Family: Chroococcaceae } \\
\text { Genus: Coelophaerium Nageli } \\
\text { Coelosphaerium sp. } \\
\text { Genus: Merismepodia Meyen } \\
\text { Merismepodia elegans Braun var. major } \\
\text { G.M. Smith }\end{array}$ & & & + & + & \\
\hline $\begin{array}{l}\text { ORDER: Nostocales } \\
\text { Family: Oscillatoriaceae } \\
\text { Genus: Oscillatoria Vaucher }\end{array}$ & & & & & \\
\hline
\end{tabular}


Table 3 contd.

\begin{tabular}{|c|c|c|c|c|c|}
\hline & ST1 & ST2 & ST3 & ST4 & ST5 \\
\hline $\begin{array}{l}\text { Oscillatoria bornettia (Kuzal) Forti } \\
\text { O. ornata Kutz } \\
\text { O. proboscidea Gomont }\end{array}$ & & & + & $\begin{array}{l}+ \\
+\end{array}$ & \\
\hline $\begin{array}{l}\text { DIVISION: EUGLENOPHYTA } \\
\text { CLASS: Euglenophyceae } \\
\text { ORDER: Euglenales }\end{array}$ & & & & & \\
\hline $\begin{array}{l}\text { Family: Euglenaceae } \\
\text { Genus: Euglena Ehrenberg } \\
\text { Euglena helecoides (Bern) Lemm. }\end{array}$ & & & & & + \\
\hline $\begin{array}{l}\text { E. sp } \\
\text { Genus: Phacus Dujardin } \\
\text { Phacus curvicauda Swir. }\end{array}$ & & & $\begin{array}{l}+ \\
+ \\
+\end{array}$ & & \\
\hline $\begin{array}{l}\text { Genus: Lepocinclis Perty } \\
\text { Lepocinclis ovum (Ehr) Lemm. var. australis } \\
\text { Playfair. } \\
\text { Genus: Trachelomonas Ehrenberg } \\
\text { Trachelomonas eurystoma var. nuda Szab. } \\
\text { T. hispida (Perty) Stein }\end{array}$ & & & & & $\begin{array}{l}+ \\
+ \\
+\end{array}$ \\
\hline
\end{tabular}

